\title{
Chapter \\ Waterbird survey at Bheemgoda Barrage and Missarpur Ganga Ghat wetlands of Haridwar district in Uttarakhand, India
}

\author{
Ashish Kumar Arya ${ }^{1,}{ }^{*}$, Kamal Kant Joshi ${ }^{2}$, \\ Archana Bachheti ${ }^{1}$ and Deepak Kumar ${ }^{3}$
}

${ }^{1}$ Graphic Era (Deemed to be University), Dehradun, India ${ }^{2}$ Graphic Era Hill University, Dehradun, India ${ }^{3}$ D.B.S. (P.G.) College, Dehradun, India

\begin{abstract}
Wetlands are areas where water is the primary factor controlling the environment and the associated plant and animal life. An attempted was made to know the health of the Ganges's wetlands ecosystem, waterbird survey was conducted between January 2019 and December 2020 in Haridwar district. Total of sixty three waterbird species, belong to fourteen families reported during the study. Out of these duck family was dominated among the families. Six species River lapwing (Vanellus duvaucelii), Black-necked stork (Ephippiorhynch usasiaticus), Woolly-necked stork (Ciconia episcopus), Painted stork (Mycteria leucocephala), River tern (Sterna aurantia) and Black-headed ibis (Threskiornis melanocephalus) were near threaten, One specie was reported endangered Black-bellied tern (Sterna acuticauda), and One vulnerable Common pochard (Aythya ferina) categories as per IUCN Red-list data. As interesting finding, we reported Asian Open bill stork (Anastomus oscitans) and Black-bellied tern (Sterna acuticauda) avian species first time in Haridwar Wetlands. The presence of avian species diversity increases the regional avian diversity of district Haridwar and emphasizes to prepare a scientific conservation strategy for the IUCN categorized waterbird species.
\end{abstract}




\section{Introduction}

Wetlands are areas where water is the primary factor controlling the environment and the associated plant and animal life. Wetlands are one of the most productive ecosystems of our natural environment (Ghermandi et al., 2010) and supported by many creatures, including birds. Wetlands are neither truly aquatic nor terrestrial; generally, it depends on seasonal variability and this transitional character of wetland creates complexity to define the boundaries of wetlands. Although, wetland has been defined as "areas of marsh, fen, peat land or water, whether natural or artificial, permanent or temporary, with water that is static or flowing, fresh, brackish or salt, including areas of marine water the depth of which at low tide does not exceed six meters" (Ramsar Convention, 1971/Article 1.1). As per the ancient records many human civilizations established near the riverine system or wetland areas because they fulfilling basic needs such as (water and food). In addition, wetlands have great cultural, social, ecological and economic values (Ramachandra et al., 2002). On the other hand; it enhances the diversity with reference to flora and fauna of that area due to their geographical location and habitat characteristics. The biological diversity of wetlands depends on the water quality and the vegetation around the wetland for the survival of the species (Buckton, 2007). In India, about 15.26 million hectares of land is cover as wetland (Prasad et al., 2002; SAC, 2011). These wetlands support the existing and growth of various flora and fauna. Total 1340 bird species have been recorded in India (Ali and Ripley, 1987; Grimmett et al., 2016) including 38 endemic species (Praveen et al., 2016). Of the total, about 310 species have been considered as wetland birds (Kumar et al., 2005).

Globally, habitat destruction (via land-use change) is one of the major issues that have been identified as the causes responsible for the loss of biodiversity (Butchart et al. 2010, Sala et al., 2000). Indian is also not untouched with degradation of wetlands and the degradation rate is high as compare to others. There are several causes have been identified that are responsible for the wetland degradation. Out of these, some are unsustainable agriculture practice, construction of human settlement around the wetlands, cattle grazing, and the construction of dams are very visible and well-known. In addition, increasing human population, unsustainable development, and lack of awareness are responsible causes to decline the wetland habitat (Ramachandra et al., 2002). Some studies have been shown the Natural calamities are also accountable for the wetland degradation (Bennett et al., 2018). Thus, wetland degradation directly influences the population of flora and fauna; it has been reported that the population of wetland birds has declined significantly from the Indian wetlands (Saikia and Bhattacharjee, 1993).

Several studies have been mentioned that wetland provides a unique habitat for many residential bird and migratory bird species (Zhijun, et al., 2010; Ghasemi, et al., 2012; Shao et al., 2014; Bhatt, 2015; Saini et al., 2017; Arya et al., 2019; Wanna et al., 2020, Arya et al., 2020). Some studies in India (Kaushik et al., 2013, Bhatt et al., 2015, Saini et al., 2017, Arya et al., 2019) have been reported wetland provides good shelter, food, and enhance the waterbird diversity. However, many wetlands in India such as Bharthpur wildlife sanctuary, Rajasthan, coastal areas of Gujarat and many more wetlands have been reported that host the thousands of migratory birds come from western and European countries 
(Agarwal, 2011). Many types of water migratory birds have migrated in India as winter visitors through the different flyways.

Now a day, these wetlands are degrading through various anthropogenic activities therefore a periodic survey on wetland avian species is required to understand the health of natural ecosystem. Water bird survey play a key role to identified the international importance of any types of wetlands (Arya et al., 2020). Very few studies have been conducted in Uttarakhand wetland area namely Missarpur Ganga Ghat and Bheemgoda barrage (Bhatt et al., 2015; Saini et al., 2017, Arya et al., 2019). The current waterbird survey was made to understand the status (present/absent basis) of waterbird species in wetlands of Haridwar district, Uttarakhand. However, a periodic monitoring on avian diversity and abundance is useful to understand the status of an ecosystem and restoration planning for habitat.

\section{Bheemgoda Barrage and Missarpur Ganga Ghat wetlands of Haridwar}

The present study was conducted between January 2019 and December 2020 in Haridwar district of Uttarakhand. The Bheemgoda barrage, is situated at the upstream region $\left(29^{\circ} 58^{\prime} \mathrm{N}, 78^{\circ} 13^{\prime} \mathrm{E}, 249.7\right.$ masl) between the Neel Dhara and the tributaries of the Ganga River under biogeographic province 4.8.4 (Indo-Gangatic Monsoon Forest), covering an area of about $2.5 \mathrm{~km}^{2}$ area, while the Missarpur wetland situated about $8 \mathrm{~km}$ away at the downstream from Bheemgoda Barrage comprising an area of about 1.5 $\mathrm{km}^{2}$, under biogeographic province 4.8.4 (Indo-Gangatic Mon-soon forest). A rich and diverse vegetation cover is available across the wetland, although some aquatic vegetation species such as Potomageton pectinatus, Eichhornia crassipes and Typha elephantine with a tree species, Dalbergia sissoo is common in the region of the Bheemgoda barrage (Figures 1 and 2).

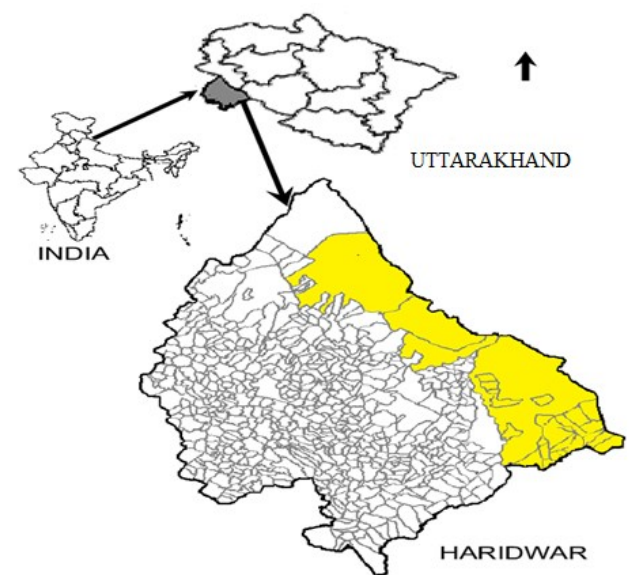

Figure 1. Map of Haridwar district selected for waterbird survey area in of Uttarakhand.
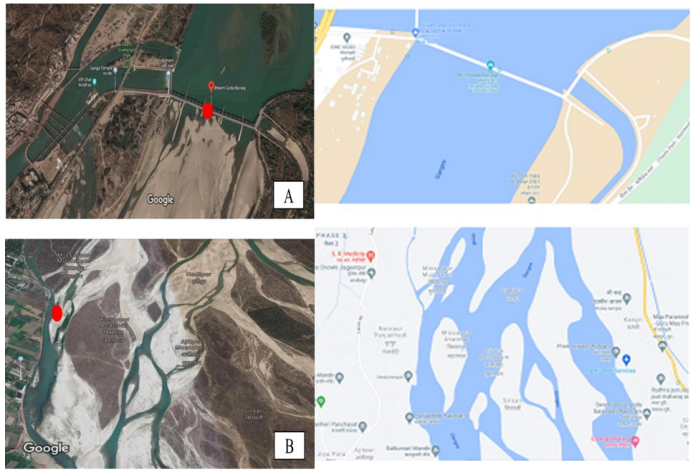

Figure 2. (A).Bheemgoda barrage (B). Missarpur wetland sites (Source: Google earth). 
On the other hand, Missarpur wetland has dominated with aquatic vegetation namely Eichhornia crassipes, Typha elephantine, Ipomeafis-tulosa, and Potomageton pectinatus. The Dalbergia sissoo tree species is dominated with mixed tree species in the area of Missarpur wetland. Haridwar has three prominent seasons like winter (October to March), summer (April to June) and Monsoon (July to September) and the temperature ranges from minimum of $4{ }^{\circ} \mathrm{C}$ in winter to a maximum $38{ }^{\circ} \mathrm{C}$ in summer (Saini et al., 2017; Arya et al., 2019). The waterbird survey was conducted from January 2019 to December 2020. Point count methods (Bibby et al., 2000) were applied for waterbird counting. The survey was completed morning 07:00 am to 11:00 am and evening 04:30 pm to 06:30 pm during summer season and between 10:00 am to 12:00 pm (morning) and 04:00 pm to 07:00 pm (evening) during winter seasons. The photographs of waterbird species were taken by the Canon SX60HS model camera and identified the species by the using field guide book (Grimmett et al., 2016).

\section{Status of waterbirds at Bheemgoda Barrage and Missarpur Ganga Ghat wetlands of Haridwar}

Total of 63 waterbird species belonging to 14 families were reported during the study period (Table 1). Anadiae family which contributes, duck spices were dominant among the waterbird species (Figure 3). However, Black Cormorant were reported dominate in Bheemgoda barrage (Figure 4). Both the wetland habitat total 37 resident, 26 winter migratory bird species were reported (Figure 5). During survey, it was reported that most of the migratory water bird species reaches both wetland habitats till the month of November and stay here at least next 5 months. In addition, Six Near threaten namely River lapwing (Vanellus duvaucelii), Black-necked stork (Ephippiorhynchus asiaticus), Woolly-necked stork (Ciconia episcopus), Painted stork (Mycteria leucocephala), River tern (Sterna aurantia) and Blackheaded ibis (Threskiornis melanocephalus).

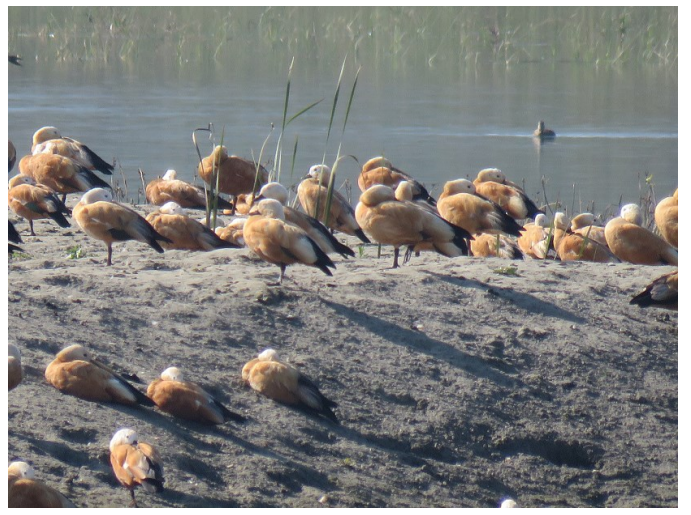

Figure 3. A Flock of duck species in Missarpur wetland of Haridwar district.

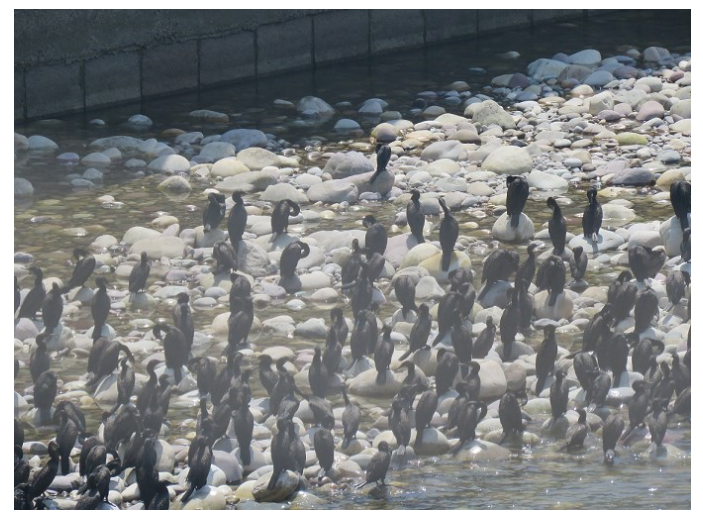

Figure 4. Black cormorant species flock in Bheemgoda barrage wetland 
Table 1. Checklist of Water Birds of Haridwar, Uttarakhand, India.

\begin{tabular}{|c|c|c|c|c|c|}
\hline Family & Common Name & Scientific Name & Status & $\begin{array}{l}\text { IUCN } \\
\text { status }\end{array}$ & $\begin{array}{l}\text { IWPA } \\
\text { Schedule }\end{array}$ \\
\hline \multirow[t]{12}{*}{ Anatidae } & Lesser Whistling-Duck & $\begin{array}{l}\text { Dendrocygna } \\
\text { javanica }\end{array}$ & WV & LC & IV \\
\hline & Bar-headed Goose & Anser indicus & WV & LC & IV \\
\hline & Ruddy Shelduck & Tadorna ferruginea & WV & $\mathrm{LC}$ & IV \\
\hline & Gadwall & Mareca strepera & WV & $\mathrm{LC}$ & IV \\
\hline & $\begin{array}{l}\text { Indian Spot-billed } \\
\text { Duck }\end{array}$ & Anas poecilorhyncha & WV & $\mathrm{LC}$ & IV \\
\hline & Mallard & Anas platyrhynchos & WV & $\mathrm{LC}$ & IV \\
\hline & Northern Pintail & Anas acuta & WV & $\mathrm{LC}$ & IV \\
\hline & Green-winged Teal & Anas crecca & WV & $\mathrm{LC}$ & IV \\
\hline & Red-crested Pochard & Netta rufina & WV & $\mathrm{LC}$ & IV \\
\hline & Common Pochard & Aythya ferina & WV & VU & IV \\
\hline & Tufted Duck & Aythya fuligula & WV & $\mathrm{LC}$ & IV \\
\hline & Common Merganser & Mergus merganser & WV & $\mathrm{LC}$ & IV \\
\hline \multirow[t]{2}{*}{ Anhingidae } & Gray Heron & Ardea cinerea & $\mathrm{R}$ & $\mathrm{LC}$ & IV \\
\hline & Purple Heron & Ardea purpurea & $\mathrm{R}$ & LC & IV \\
\hline \multirow[t]{7}{*}{ Ardeidae } & Great Egret & Ardea alba & $\mathrm{R}$ & $\mathrm{LC}$ & IV \\
\hline & Intermediate Egret & Ardea intermedia & $\mathrm{R}$ & $\mathrm{LC}$ & IV \\
\hline & Little Egret & Egretta garzetta & $\mathrm{R}$ & $\mathrm{LC}$ & IV \\
\hline & Cattle Egret & Bubulcus ibis & $\mathrm{R}$ & $\mathrm{LC}$ & IV \\
\hline & Indian Pond-Heron & Ardeola grayii & $\mathrm{R}$ & $\mathrm{LC}$ & IV \\
\hline & Striated Heron & Butorides striata & $\mathrm{R}$ & $\mathrm{LC}$ & IV \\
\hline & $\begin{array}{l}\text { Black-crowned } \\
\text { Night-Heron }\end{array}$ & Nycticorax nycticorax & $\mathrm{R}$ & $\mathrm{LC}$ & IV \\
\hline \multirow[t]{3}{*}{ Burhinidae } & Eurasian thick-knee & Burhinusoedienemus & $\mathrm{R}$ & LC & IV \\
\hline & Indian thick-knee & Burhinusindicus & $\mathrm{R}$ & $\mathrm{LC}$ & IV \\
\hline & Great thick-knee & Esacusrecurvirostris & $\mathrm{R}$ & $\mathrm{LC}$ & IV \\
\hline \multirow[t]{6}{*}{ Charadriidae } & Northern Lapwing & Vanellus vanellus & $\mathrm{R}$ & NT & IV \\
\hline & River Lapwing & Vanellus duvaucelii & $\mathrm{R}$ & NT & IV \\
\hline & $\begin{array}{l}\text { Yellow-wattled } \\
\text { Lapwing }\end{array}$ & Vanellus malabaricus & $\mathrm{R}$ & $\mathrm{LC}$ & IV \\
\hline & Red-wattled Lapwing & Vanellus indicus & $\mathrm{R}$ & $\mathrm{LC}$ & IV \\
\hline & White-tailed Lapwing & Vanellus leucurus & $\mathrm{R}$ & $\mathrm{LC}$ & IV \\
\hline & Little Ringed Plover & Charadrius dubius & $\mathrm{WV}$ & $\mathrm{LC}$ & IV \\
\hline \multirow[t]{5}{*}{ Ciconiidae } & Asian Open bill & Anastomus oscitans & $\mathrm{R}$ & $\mathrm{LC}$ & IV \\
\hline & Black Stork & Ciconia nigra & WV & $\mathrm{LC}$ & IV \\
\hline & Woolly-necked Stork & Ciconia episcopus & $\mathrm{R}$ & NT & IV \\
\hline & Black-necked Stork & $\begin{array}{l}\text { Ephippiorhynchus } \\
\text { asiaticus }\end{array}$ & WV & NT & IV \\
\hline & Painted Stork & Myctria leucocephala & $\mathrm{R}$ & NT & IV \\
\hline
\end{tabular}


Table 1. Continued...

\begin{tabular}{|c|c|c|c|c|c|}
\hline Family & Common Name & Scientific Name & Status & $\begin{array}{l}\text { IUCN } \\
\text { status }\end{array}$ & $\begin{array}{l}\text { IWPA } \\
\text { Schedule }\end{array}$ \\
\hline \multirow[t]{3}{*}{ Hirundinidae } & Gray-throated Martin & Riparia chinensis & $\mathrm{R}$ & $\mathrm{LC}$ & IV \\
\hline & Barn Swallow & Hirundo rustica & $\mathrm{R}$ & $\mathrm{LC}$ & IV \\
\hline & Wire-tailed Swallow & Hirundo smithii & $\mathrm{R}$ & $\mathrm{LC}$ & IV \\
\hline \multirow[t]{2}{*}{ Jacanidae } & Pheasant-tailed Jacana & $\begin{array}{l}\text { Hydrophasianus } \\
\text { chirurgus }\end{array}$ & $\mathrm{R}$ & $\mathrm{LC}$ & IV \\
\hline & Bronze-winged Jacana & Metopidius indicus & $\mathrm{R}$ & LC & IV \\
\hline \multirow[t]{7}{*}{ Laridae } & Black-headed Gull & $\begin{array}{l}\text { Chroicocephalus } \\
\text { ridibundus }\end{array}$ & WV & LC & IV \\
\hline & Brown-headed Gull & $\begin{array}{l}\text { Chroicocephalus } \\
\text { brunnicephalus }\end{array}$ & WV & LC & IV \\
\hline & Pallas's Gull & $\begin{array}{l}\text { Ichthyaetus } \\
\text { ichthyaetus }\end{array}$ & WV & LC & IV \\
\hline & Caspian Gull & Larus cachinnans & WV & $\mathrm{LC}$ & IV \\
\hline & Little Tern & Sternula albifrons & WV & $\mathrm{LC}$ & IV \\
\hline & River Tern & Sterna aurantia & WV & NT & IV \\
\hline & Black-bellied tern & Sterna acuticauda & $\mathrm{R}$ & EN & IV \\
\hline Pha- & Little Cormorant & Microcarbo niger & $\mathrm{R}$ & $\mathrm{LC}$ & IV \\
\hline $\begin{array}{l}\text { lacrocoracida } \\
\text { e }\end{array}$ & Great Cormorant & Phalacrocorax carbo & $\mathrm{R}$ & $\mathrm{LC}$ & IV \\
\hline \multirow{7}{*}{$\begin{array}{l}\text { Podici- } \\
\text { pedidae } \\
\text { Rallidae }\end{array}$} & Great Crested Grebe & Podicep scristatus & WV & $\mathrm{LC}$ & IV \\
\hline & Little Grebe & Tachybaptus ruficollis & $\mathrm{R}$ & $\mathrm{LC}$ & IV \\
\hline & Eurasian Moorhen & Gallinula chloropus & $\mathrm{R}$ & LC & IV \\
\hline & Eurasian Coot & Fulica atra & WV & LC & IV \\
\hline & $\begin{array}{l}\text { Gray-headed Swamp } \\
\text { hen }\end{array}$ & $\begin{array}{l}\text { Porphrio } \\
\text { poliocephalus }\end{array}$ & WV & $\mathrm{LC}$ & IV \\
\hline & Water cock & Gallicrex cinerea & $\mathrm{R}$ & $\mathrm{LC}$ & IV \\
\hline & Common moorhen & Gallinula chloropus & WV & $\mathrm{LC}$ & IV \\
\hline \multirow[t]{2}{*}{$\begin{array}{l}\text { Recurvirostri- } \\
\text { dae }\end{array}$} & Black-winged Stilt & $\begin{array}{l}\text { Himantopus } \\
\text { himantopus }\end{array}$ & $\mathrm{R}$ & LC & IV \\
\hline & Pied Avocet & $\begin{array}{l}\text { Recurvirostra } \\
\text { avosetta }\end{array}$ & $\mathrm{R}$ & LC & IV \\
\hline \multirow[t]{5}{*}{ Scolopacidae } & Common Sandpiper & Actitis hypoleucos & $\mathrm{R}$ & $\mathrm{LC}$ & IV \\
\hline & Green Sandpiper & Tringa ochropus & $\mathrm{R}$ & LC & IV \\
\hline & Common Greenshank & Tringa nebularia & $\mathrm{R}$ & $\mathrm{LC}$ & IV \\
\hline & Marsh Sandpiper & Tringa stagnatilis & $\mathrm{R}$ & $\mathrm{LC}$ & IV \\
\hline & Common Redshank & Tringa totanus & $\mathrm{R}$ & $\mathrm{LC}$ & IV \\
\hline
\end{tabular}

$\mathrm{R}=$ Staying in one place all the year, non-migratory; $\mathrm{WV}=\mathrm{A}$ winter migrant to India which breeds in Eurasia and visits India in winter, LC= Least Concern, NT= Near Threatened, EN= Endangered, IUCN= International Union for Conservation of Nature

One endangered Black bellied tern (Sterna acuticauda), and one vulnerable species Common Pochard (Aythya ferina) categories as per IUCN red-list were also reported during survey. Some of the threaten species namely River tern (Sterna aurantia), River lapwing (Vanellus duvaucelii), and Black-necked Stork (Ephippiorhynchus asiaticus) are shown in the Figures 6a-6c. 


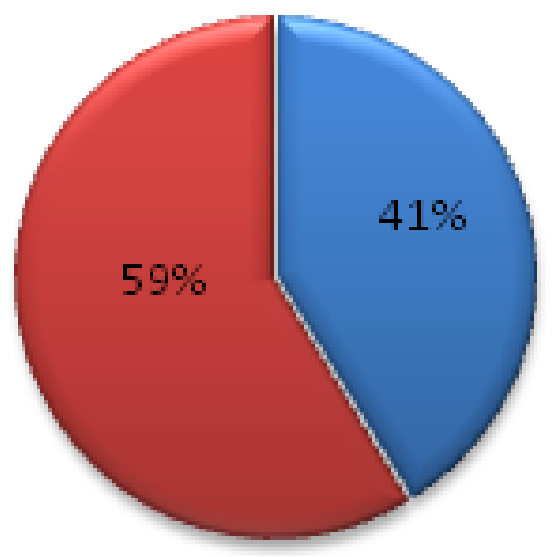

- Winter Visitor

$\square$ Resident

Figure 5. Status of waterbird species (in \%) from the Bheemgoda barrage and Misserpur wetland habitat of the study area.

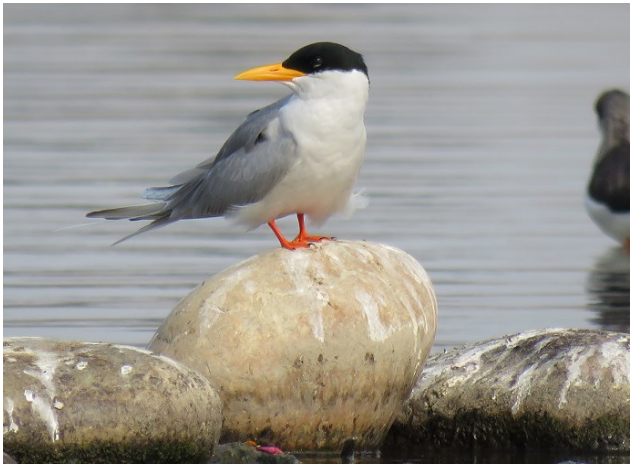

Figure 6a. River tern (Sterna aurantia)

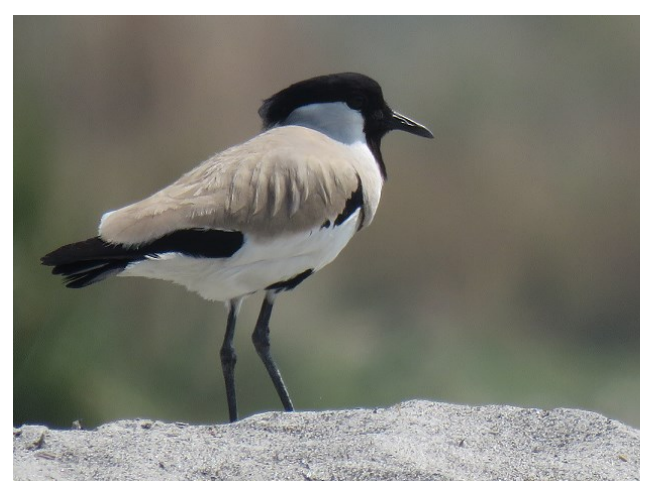

Figure 6b. River lapwing (Vanellus duvaucelii)

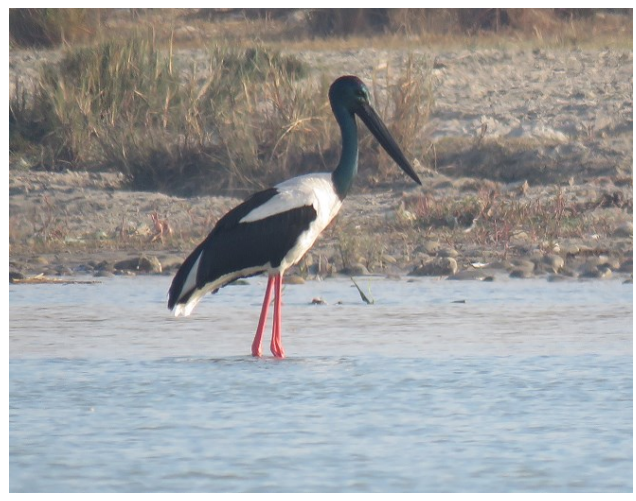

Figure 6c. Black-necked Stork (Ephippiorhynchus asiaticus) 


\section{Conclusion}

The presence of residence and migratory water bird species enhance the local avian biodiversity of the Haridwar district. The availability of near threaten, and endangered species in the study area indicates the both the wetlands are suitable or less disturb habitat for the waterbird species. The available water bird species data will helpful for the researchers and this base line data will also helpful for the further study in Haridwar wetland.

\section{References}

Agarwal, M. (2011). Migratory birds in India: Migratory birds dwindling, New Global Indian (http://newglobalindian.com/ nature).

Ali, S., Ripley, S. D. and Dick, J. H. (1987). Compact handbook of the birds of India and Pakistan.

Amezaga, J. M., Santamaria, L. and Green, A. J. (2002). Biotic wetland connectivity: Supporting a new approach for wetland policy. ActaOecologica, (23): 213-222

Arya, A.K., Bhatt, D., Singh, A., Saini, V., Verma, P., Rathi, R. and Bhatnagar, P. (2019). Diversity and status of migratory and resident wetland birds in Haridwar, Uttarakhand, India. Journal of Applied and Natural Science, 11(3): 732-737.

Arya, A.K., Joshi, K.K., and Bachheti, A. (2020). A review on distribution and importance of wetlands in the perspective of India. Journal of Applied and Natural Science, 12(4): 710-720.

Arya, A.K., Joshi, K.K., Bachheti, A., Raturi, V., Dubey, V. P., Bhatnagar, P. and Rawat, R. (2020) Avian Survey at Haiderpur Wetland in Hastinapur Wildlife Sanctuary Uttar Pradesh, India. Journal of Environment and Bio-Sciences, 34(2): 107-114.

Bhatt, D., Sethi, V.K., Sharma S., Kumar, A., Saini V. and Singh A. (2015) Water birds of selected wetlands of Uttarakhand. ENVIS, WII, Dehradun.

Bibby, C.J., Burgess, N.D., Hill, D.A. and Mustoe, S. (2000). Bird census Techniques. Elsevier, Amsterdam, Netherlands

Buckton, S. (2007). Managing wetlands for sustainable livelihoods at Koshi Tappu. Danphe, 16(1): 12-13.

Butchart, S.H., Walpole, M., Collen, B., Van Strien, A., Scharlemann, J.P., Almond, R.E., Baillie, J.E., Bomhard, B., Brown, C. and Bruno, J. (2010). Global biodiversity: Indicators of recent declines. Science, 328(5982): 1164-1168.

Ghasemi, S., Mola-Hoveizeh, N., Zakaria, M., Ismail, A. and Tayefeh, F.H. (2012). Relative abundance and diversity of waterbirds in a Persian Gulf mangrove forest, Iran. Tropical Zoology, 25(1): 39-53.

Ghermandi, A., Van Den Bergh, J.C., Brander, L.M., De Groot, H.L. and Nunes, P.A. (2010). Values of natural and humanmade wetlands: A meta-analysis. Water Resources Research, 46: 1-12.

Grimmett, R., Inskipp, C. and Inskipp, T. (2016). Birds of the Indian Subcontinent: India, Pakistan, Sri Lanka, Nepal, Bhutan, Bangladesh and the Maldives. Bloomsbury Pubshing. https://doi.org/10.31018jans.v11i3.2085.

Kaushik, T.K. and Gupta, R.C. (2013). Understanding and analyzing the coordinates of diversity of wetland birds of Asan Barrage near Paonta Sahib, Northern India. Our Nature, 11(2): 192-200.

Kumar, A., Sati, J.P., Tak, P.C. and Alfred, J.R.B. (2005). Handbook on Indian Wetland Birds and their Conservation: i-xxvi; 1468 (Published by the Director, Zool. Surv. India).

Ma, Z., Cai, Y., Li, B. and Chen, J. (2010). Managing wetland habitats for waterbirds: an international perspective. Wetlands, 30 (1): $15-27$.

Prasad, S.N., Ramachandra, T.V., Ahalya, N., Sengupta, T., Kumar, A., Tiwari, A.K., Vijayan, V.S. and Vijayan, L. (2002). Conservation of wetlands of India a review. Tropical Ecology: 43(1): 173-186.

Praveen, J., Jayapal, R. and Pittie, A. (2016). A checklist of the birds of India. Indian BIRDS, 11(5): 113-172.

Ramachandra, T.V., Kiran, R., Ahalya, N. and Deepa, R.S. (2002). Status of wetlands in Bangalore. CES Technical Report. 
Ramsar Convention (1971). The Ramsar Convention. Ramsar Center, Rue Mauverney 28, CH 1196, Gland, Switzerland.

SAC (2011). National wetland atlas. Space application center (SAC). Indian Space Research Organisation (ISRO), Ahmedabad, India.

Saikia, P. and Bhattacharjee, P.C. (1993). Status, diversity and decline of waterbirds in Brahmputra valley, Assam, India. pp. 20-27. in Verghese, A., Sridhar, S. and Chakravarthy, A.K. (eds.) Bird Conservation, Strategies for the Nineties and Beyond. Ornithological Society of India, Bangalore.

Saini, V., Joshi, K., Bhatt, D., Singh, A. and Joshi, R. (2017). Waterbird species distribution between natural and manmade wetland in Himalayan foothills of Uttarakhand, India. Biodiversitas Journal of Biological Diversity, 18(1): 1-10.

Sala, O.E., Chapin, F.S., Armesto, J.J., Berlow, E., Bloomfield, J., Dirzo, R., Huber-Sanwald, E., Huenneke, L.F., Jackson, R.B. and Kinzig, A. (2000). Global biodiversity scenarios for the year 2100. Science, 287(5459): 1770-1774.

Shao, M., Jiang, J., Guo, H. and Zeng, B. (2014). Abundance, distribution and diversity variations of wintering water birds in Poyang Lake, Jiangxi Province, China. Pakistan Journal of Zoology, 46(2): 1-20.

Wanna, C., Wasan, D., Pisarut, Y. and Rungtip, S.A. (2020). The diversity, population, ecology and conservation status of waterbirds in the wetland of Bangpu Nature Education Center, Thailand. Biodiversitas Journal of Biological Diversity, 21 (8): 10-24.

$* * * * *$

Cite this chapter as: Arya, A.K., Joshi, K.K., Bacheti, A. and Kumar, D. (2021). Waterbird survey at Bheemgoda Barrage and Missarpur Ganga Ghat wetlands of Haridwar district in Uttarakhand, India. In: Biological Diversity: Current Status and Conservation Policies, Volume 1, Eds. Kumar., V., Kumar, S., Kamboj, N., Payum, T., Kumar, P. and Kumari, S. pp. 193-201, https://doi.org/10.26832/aesa2021-bdcp-012 